\title{
Pithonellid blooms in the Chalk of the Isle of Wight and their
} biostratigraphical potential

\author{
Wilkinson, I.P. \\ British Geological Survey, Nottingham, NG12 5GG
}

\begin{abstract}
Five pithonellid blooms recognised in the Chalk Group of the Isle of Wight are correlated via foraminiferal biostratigraphy to regional and global events. Blooms were recognised in the Holywell Nodular Chalk to basal New Pit Chalk formations (foraminiferal zones BGS7 to BGS9); M. guerangeri to Mytiloides standard macrofaunal zones); middle Lewes Chalk (questionably foraminifera Zone BGS12; $S$. plana standard macrofaunal Zone); basal Seaford Chalk (BGS14; base $M$. coranguinum standard macrofaunal Zone); lower Newhaven Chalk (base BGS18; base U. socialis standard macrofaunal Zone); and uppermost Newhaven to basal Culver formations (BGS19-20; O. pilula to low G. quadrata standard macrofaunal zones). The blooms appear to be coeval with oceanographic change and the general trend towards an increase in the proportion of planktonic taxa may suggest upwelling and/or dysaerobic bottom waters.
\end{abstract}

Key words: Pithonellids; Late Cretaceous; stratigraphy; Isle of Wight

\section{Introduction}

During recent surveying of the Chalk Group of the Isle of Wight by the British Geological Survey, samples were collected from pits, quarries and other exposures along the chalk outcrop (Fig. 1). Biostratigraphical control was provided principally by 
foraminifera (Wilkinson, herein), but during analysis, pithonellids (or 'calcispheres'), were observed in abundance at several discrete horizons, whilst at other levels these microfossils were rare or absent. Blooms have been observed in Upper Cretaceous deposits on most continents and Bignot and Leuzaud (1964) suggested that their abundance could be used biostratigraphically. This notion that was confirmed by Villain (1977), although he was more circumspect, opining that this method of biostratigraphy was only applicable at a local scale. In order to determine their stratigraphical usefulness in the Isle of Wight, the pithonellid-rich chalks were confined biostratigraphically (on the basis of the associated microfaunal content) and stratigraphically (within the established lithostratigraphical framework of the Chalk Group) in an attempt to correlate horizons on the island with those elsewhere in Britain. Induration of the Chalk varies considerably across the Isle of Wight, such that investigation of the microfossils in the harder chalks was carried out by thin sections, while softer chalks were disaggregated and microfossils examined in 3-D. All samples are deposited in the Biostratigraphical Collection of the British Geological Survey, Nottingham, under the prefix 'MPA'. All National Grid References (N.G.R.) are within $100 \mathrm{~km}$ square SZ.

\section{2. 'Calcispheres' and pithonellids}

Pithonellids form simple, hollow, calcareous spheroids up to $0.5 \mathrm{~mm}$ in diameter, varying from spherical to ovate and subcylindrical, and some are ornamented with striations. There is some evidence that they originally had granular to acicular aragonitic walls (Marszalek, 1975), arranged in one or two (and very rarely three) layers. The crystals comprising the wall were disposed obliquely (Keupp, 1987) resulting in linear, spiral or 'parquet-like' arrangement on the wall surface. An apical aperture ('archaeopyle') is also preserved in some specimens (e.g. Streng et al., 2004). 
There has been much debate as to the biological affinities of 'calcispheres'. The earliest work was by Kauffman (1865) who considered them to be foraminifera, placing them into the genus Lagena. Others have considered them to be foraminifera, protozoan, spores of dasyclad algae or nannoplankton (e.g. Colom, 1955; Adams et al., 1967; Banner, 1972; Masters and Scott, 1978; Tappan, 1980). The view that has found most favour, however, is that they were calcareous dinoflagellates (Subfamily Calciodinelloideae Fensome et al., 1993), a concept postulated by Fütterer (1976). However, Fensome et al. (1993) and Streng et al. (2004) questioned this and Wendler and Willems (2004) concluded that “... microfossils of the genus Pithonella are most probably calcareous dinoflagellate cysts.... [but] .... they are taxonomically very problematic and evidence is needed to evaluate their affinity with the dinoflagellates."

\section{Distribution of pithonellid blooms in the Late Cretaceous}

There are many examples of pithonellid blooms within Cretaceous successions, in some cases creating pithonellid wackestones and packstones, e.g. in France (Dufaure, 1959; Bignot and Lezaud, 1964; Villain, 1977; Robaszynski et al 2005), Iran (Adams et al.,1967), India (Bertle and Suttner, 2005), S. England (Banner, 1972; Hart 1991; Gale et al 2000; Mortimore et al., 2001), Israel (Bein and Reiss, 1976), Poland (Olszewska-Nejbert, 2004), Portugal (Hart et al., 2005), Germany (Niebuhr, 2005), USA (Tew, 2000), Mexico (Aguilera-Franco, 2003) and Antarctica (Fütterer, 1990).

The cause of the blooms has been ascribed to favourable palaeoenvironmental conditions, although the environmental requirements of pithonellids are not fully understood. The distribution of Cretaceous pithonellids suggests that they favoured low palaeolatitudes and appear to be at their northern limit in Yorkshire, England (Thomas 1932), Southern North Sea Basin (Kennedy, 1987) and Lägerdorf and Isle of Rügen, 
northern Germany (Villain, 1977; Willems, 1992) and Stevns Klint, Denmark (Wendler and Willems, 2002). It has been suggested that they showed a preference for open-ocean (e.g. Adams et al., 1967; Bishop, 1972) and outer shelf (Villain, 1981) environments, but they have also been reported in carbonate-rich inter-reefal deposits (Bein and Reiss, 1976) and back-reef lagoonal environments (Masters and Scott, 1978). Wendler et al. (2002) showed that it was possible to characterise the Cenomanian oceanic, outer shelf and marginal shelf mileux on the basis of Calciodinelloideae. The blooms in the Cretaceous of the Isle of Wight all took place in outer shelf conditions (in the sense of Wendler et al., 2002), but generally at times of high sea levels (Fig.2).

Robaszynski et al. (1993) and Hart (1991) suggested that the sudden 'floods' of Pithonella were due to oceanographic change such as the early phase of transgression during sea-level fluctuations. Although this is the case for some transgressive events (Fig. 2), others (particularly those in the lower to middle Cenomanian and early to mid Campanian) lack blooms suggesting that the trigger was not sea level change alone. Other palaeoceanographic changes must have play a part. For example, rhythms of chalky marl (foraminiferal and nannofossil wackestones with abundant clastic material) and indurated limestone (calcisphere wackestones and packstones with little terrigenous clastic detritus) during the Campanian of the USA, may indicate periodic reductions in turbidity, leading to palaeoceanographic conditions favourable for blooms (Tew, 2000). Hart et al. (2005) suggested that the sudden influx of late Cenomanian-early Turonian pithonellids may be related to the Bonarelli Oceanic Anoxic Event. It also seems plausible that the cause for the blooms was related to phases of upwelling, resulting in the nutrient enrichment of the photic zone by, for example, nitrates and phosphates. The source of the nutrients may have been the 
reworking of the black shales during the opening of the Atlantic, sea-level change or variability in deep water ocean circulation.

\section{Pithonellid blooms in southern England}

Banner (1972) was the first to document blooms of Pithonella in the Cenomanian of the Isle of Wight. He stated that the 'floods' occurred in Bands 2 and 3 of the "Chalk Marl" (in the sense of Kennedy, 1969) at Culver Cliff and considered them to be of $M$. mantelli zonal age. However, he went on to list the associated foraminifera (Praeglobotruncana stephani, Arenobulimina anglica and Pseudotextulariella cretosa), the concurrent range of which would place the faunas in the costatus Subzone (rhotomagense standard macrofaunal Zone). In modern lithostratigraphical terms, this would place the 'floods' of Pithonella within the Zigzag Chalk Formation. Similar blooms were observed in borehole material from the English Channel (Curry and Smith, 1975) with foraminifera including (by original designation) Pseudovalvulineria globosa, Gavelinopsis turonica, Hedbergella portsdownensis, Eouvigerina stormi and Heterohelix sp.; the assemblages were considered to be early Turonian in age based on the flood of Pithonella.

Hart (in Hart et al., 2005) recorded the appearance of common Pithonella in the gerangeri zone (Zigzag Chalk Formation) at Eastbourne, although they became more abundant in the Plenus Marl, reaching 'flood' proportions in the juddi zone at the base of the Holywell Nodular Chalk (Dover Chalk Formation sensu Hart et al., 2005) at which point they began to decline in numbers again (Fig. 3). Similar 'floods' are known from this stratigraphical level elsewhere in southern England, including the lower Turonian at Hooken Cliff, Beer (basal Connet's Hole Member of the Seaton Chalk Formation sensu Hart, 1991), Dover (in the Shakespeare Cliff Member sensu 
Jarvis et al., 1988; Hart, 1991) and at Membury (the Mytiloides spp. macrofaunal zone at the base of the Holywell Nodular Chalk Formation) (Hart 1991; Mortimore et al., 2001). Gale et al. (2000) also recorded the presence of pithonellids in the guerangeri macrofaunal Zone of the Zigzag Chalk Formation (their Grey Chalk Member) and the M geslinianum macrofaunal Zone (Plenus Marl) of Eastbourne, Sussex. However, the major increase in abundance took place in "couplet E6" in the uppermost $M$. geslinianum macrofaunal Zone (at the base of Ballard Cliff Member, sensu Mortimore et al., 2001) and the decline began in the W. devonense Zone (= low in the Mytilioides spp. Zone herein) during the early Turonian (Fig. 3).

Higher in the succession, blooms are less well known, although Pithonella-rich, nodular chalk has been recorded from the late Turonian Lewes Tubular Flints (S plana Macrofaunal Zone) in the Lewes Nodular Chalk Formation in Sussex (Mortimore et al., 2001, page 13) (Fig. 3). Here, both Pithonella sphaerica and P. ovalis were illustrated, although no details of the vertical distribution of the bloom were given. This 'flood' appears to correlate with the Turonian "calcisphere and flaser chalk" which are situated as high as the Lewes Tubular Flints south-east of Paris (Robaszynski et al., 2005).

Pithonellid blooms have not been recorded in stratigraphically higher chalks of southern England, although they have been recorded in the Middle to Upper Campanian and Upper Maastrichtian of Mainland Europe.

\section{Pithonellid blooms on the Isle of Wight}

Although pithonellids were rare or absent in the majority of samples examined from the Isle of Wight, they were common and abundant at several distinct horizons (Fig. 3). 
The West Melbury Marly Chalk Formation contained only very rare or rare pithonellids throughout the unit, the foraminiferal association being characterised by numerous agglutinated benthonic foraminifera of Foraminiferal Zones BGS1- BGS4i (for an overview of the foraminifera of the Chalk of southern England and their biostratigraphical distribution, see Wilkinson, herein).

The Zigzag Chalk Formation of the Isle of Wight contains a characteristic foraminiferal fauna. Long ranging Cenomanian taxa are accompanied by species with a more restricted distribution such as Rotalipora cushmani, Lingulogavelinella globosa, Gavelinella tourainensis, Plectina cenomana and Pseudotextulariella cretosa. Pithonella is generally rare in the lower part of the Zigzag Chalk Formation, but in the upper part (particularly foraminiferal zones BGS5 and BGS6 sensu Wilkinson, herein, which equate to the A. jukesbrownei and $C$ guerangeri macrofaunal zones) they become more frequent. A thin section from the indurated Upper Zigzag Chalk Formation at Bembridge Down (MPA57102; N.G.R.62630 85687) has yielded abundant Pithonella sphaerica and a foraminiferal assemblage (including Lingulogavelinella globosa, Plectina cenomana and Gavelinella cenomanica) characteristic of BGS6. The Zigzag Chalk Formation to the NE of Yaverland Manor Farm (MPA57090; N.G.R. 61583 86163) contained very rare, long-ranging Cenomanian benthonic foraminifera and frequent, simple, non-keeled planktonic species (e.g. Hedbergella delrioensis). Floods of Pithonella sphaerica accompanied these foraminiferal assemblages, together with rare Pithonella ovalis and very rare, questionable Orthopithonella, although other species recorded from Escalles, Northern France (Wendler et al., 2002), such as Cubodinellum renei and Pentadinellum vimineum Keupp, 1987, were not observed. 
The Holywell Chalk Formation on Cheverton Down, NW of Shorwell, Mottistone Down and Luccombe Down contained Pithonella-rich chalks dating to foraminiferal zones BGS8 and BGS9. At Cheverton Down, foraminifera tended to be sparse and of low diversity, but Gavelinella berthelini, Gavelinella tourainensis, Lingulogavelinella globosa, Tritaxia jongmansi, Hedbergella planispira and Helvetoglobotruncana helvetica. indicate a position within foraminiferal Zone BGS9 (sensu Wilkinson, herein).

Pithonella-rich samples in the lower part of the Holywell formation on Mottistone Down (MPA58133; N.G.R.44081 84508) contain sparse foraminifera including Tritaxia tricarinata and Arenobulimina sp. cf. preslii. Although equivocal a position within BGS8 is suggested. Foraminifera (including rare Gyroidina praestans and Gavelinella cf tourainensis) were sparse at N.G.R. 4582784169 (MPA57150), to the north of Shorwell, and on Luccombe Down MPA57162 (N.G.R. 57551 79805), although in contrast, Pithonella blooms comprised abundant Pithonella sphaerica and rare P. ovalis.

The New Pit Chalk Formation contains a bloom of very small (less than 125 microns) Pithonella sphaerica in its lower part, west of Culver Cliff (MPA57103; N.G.R. 62960 85576). The planktonic foraminiferal assemblage here comprises essentially longranging species (but no lower than BGS 10), including Helvetoglobotruncana helvetica and Dicarinella canaliculata. The former is confined to the Mytiloides and T. lata macrofaunal zones, and is associated particularly with the Holwell and New Pit chalk formations, although it ranges up into the lower Lewes Chalk. The latter species first appears near the base of the T. lata macrofaunal Zone in the lower New Pit Chalk. Pithonella becomes rare towards the top of the formation. 
The Lewes Chalk Formation of the Isle of Wight generally contains only rare specimens of Pithonella. However, a thin section from Brading Down (MPA57084; N.G.R. 59920 86705) contained abundant, very small specimens of Pithonella sphaerica together with a sparse assemblage of indeterminate benthonic foraminifera with unkeeled, long-ranging planktonic taxa such as Hedbergella and Heterohelix and very rare, keeled Marginotruncana marginata. It is not possible to confine the stratigraphical position of the sample accurately, but the Lewes Tabular Flints in the $S$. plana macrofaunal Zone contains a bloom of Pithonella (cf. Mortimore et al., 2001).

The Seaford Chalk Formation generally yields only rare assemblages of Pithonella, although raised numbers have been found on the Isle of Wight. A thin section from the northern side of Bembridge Fort (MPA57097; N.G.R. 62394 86179) contains the foraminifera Gavelinella ammonoides, Reusella kelleri, Eouvigerina aculeata, Osangularia cordieriana, Stensioeina sp. cf. granulata, Globorotalites michelinianus and a specimen of Gavelinella tentatively assigned to G. cristata. If the last named is correctly identified, a position in foraminiferal zone BGS18 the highest Seaford Chalk can be suggested. Reussella kelleri is normally absent through much of the Seaford Chalk although it is present towards the base of the unit and above the Whitaker 3" Flint and lateral equivalents.

A similar assemblage was found in the basal part of the unit on Mersley Down (MPA57074; N.G.R. 56080 87282), although Stensioeina sp. cf. granulata was also present. The genus Stensioeina first appears consistently in the English chalk at the base of Foraminiferal zone BGS14. Pithonella is common in the sample from Bembridge Fort and frequent on Mersley Down, and although it does not constitute a 'flood', their raised frequency takes place at a horizon that has not previously been noted in the English Chalk. 
The Newhaven Chalk Formation generally contains rare Pithonella, but P. sphaerica is frequent to common at East Afton Down, Little Down, Brighstone Down, Mottistone Down, Newbarn Down and Mersley Down. Foraminifera in the lower part of the formation at East Afton Down (MPA59667; N.G.R.36297 85801) included Gavelinella cristata, G. stelligera, Reussella szajnochae praecursor and Stensioeina granulata perfecta (although species of Bolivinoides were absent), and placed in foraminiferal zone BGS18ii. Although Pithonella did not occur in 'flood' proportions, they were common at this locality, notably in the 72-125 micron sieve fraction. On Little Down (MPA59609; N.G.R. 4350 8619), Brighstone Down (MPA59605; N.G.R. 4271 8484) and Mottistone Down (MPA59600; N.G.R. 4067 8518), frequent Pithonella occurred with Gavelinella cristata, G. stelligera, Reussella szajnochae praecursor, R. kelleri and Stensioeina granulata incondita. A specimen of S. granulata granulata was also present, a species that is very rare in the upper part of its range, but appears to go into extinction in the late Santonian. Foraminiferal zone BGS18iii is indicated.

A bloom of Pithonella sphaerica was observed at Newbarn Down (MPA59607; N.G.R. 4306 8581), Mersley Down (MPA57076; N.G.R. 56224 87549), and Little Down (MPA59610; N.G.R. 4355 8639). The foraminifera association included Gavelinella crista, G. stelligera, Reussella kelleri, Stensioeina granulata incondita and Bolivinoides culverensis with Stensioeina pommerana on Mersley Down (MPA57076 N.G.R. 56224 87549) indicating foraminiferal zone BGS19 (approximately equivalent to the standard $O$. pilula macrofaunal Zone).

The Culver Chalk Formation at the western end of the island also yielded common pithonellids, examples being noted at West High Down, the western end of Pay Down and Newbarn Down. The Lower Culver Chalk at Newbarn Down (MPA59603; N.G.R. 42658559 ) contained frequent pithonellids together with a characteristic foraminiferal 
assemblage including Gavelinella usakensis, Bolivinoides culverensis, Gavelinella thalmanni, Stensioeina granulata incondita and Neoflabellina rugosa, which is considered to be indicative of BGS20i. Frequent pithonellids (all of very small dimensions) were identified from west of the Coastguard Station, West High Down (MPA59619; N.G.R. 29794 84839) where a sparse foraminiferal association included Gavelinella usakensis, G. trochus and Stensioeina pommerana and although several key indices were not observed, the assemblage is placed in foraminiferal zone BGS 20 (probably subzones BGS20ii or BGS20iii). An assemblage, characterised by Gavelinella usakensis, Bolivinoides culverensis, Stensioeina granulata incondita and S. pommerana was found on Pay Down, 650 m SE of Shalcombe Manor (MPA59598; N.G.R. 4001 8524) and is of a similar age to that at West High Down. Here common pithonellids were observed in the 72-125 micron sieve fraction. A similar fauna was recorded in a thin section of indurated Culver Chalk Formation at Ashey Down (MPA57080; N.G.R. 57700 87929), north west of Brading. Gavelinella usakensis and Bolivinoides sp. (with an outline closer to $B$. culverensis than the more kite-shaped $B$. decoratus) were present, characteristic of BGS20. Specimens of Pithonella sphaerica were common at this horizon, but accompanied by rare Pirumella. krasheninnikovi, which is known to range between the late Campanian and early Maastrichtian in the north Atlantic (Pflaumann and Krasheninnikov, 1978). A thin section from Culver Down NW of the gun emplacement (MPA57108; N.G.R. 63357 85695) also contains Gavelinella usakensis, together with Globotruncana linneiana and frequent Pithonella sphaerica. The influx of pithonellids at this stratigraphical horizon may be related to the bloom at about the mid-late Campanian boundary interval recognised in mainland Europe (Villain, 1977; Willems, 1992) and France (Bignot and Lezaud, 1964; Villain 1977). 
The Portsdown Chalk to the west of Carisbrook on the northern edge of Bowcombe

\section{Conclusions}

Pithonella is generally rare or very rare in the Chalk Group of the Isle of Wight, although five blooms can be recognised: Holywell Nodular Chalk to basal New Pit Chalk (foraminiferal zones BGS7 to BGS9; M. guerangeri to Mytiloides standard macrofaunal zones), middle Lewes Chalk (questionably foraminifera Zone BGS12; $S$. plana standard macrofaunal Zone), base Seaford Chalk (BGS14; base M. coranguinum standard macrofaunal Zone), lower Newhaven Chalk (base BGS18; base U. socialis standard macrofaunal Zone) and uppermost Newhaven to basal Culver formations (BGS19-20; O. pilula to low G. quadrata standard macrofaunal zones). The blooms appear to correlate with the larger maximum flooding surfaces when widespread oceanographic change took place. The blooms of pithonellids and the general trend towards an increase in the proportion of planktonic, compared to benthonic, foraminifera at these events, may suggest upwelling and/or dysaerobic bottom waters.

The two species of Pithonella that bloomed during the Cretaceous of the Isle of Wight, $P$. sphaerica and $P$. ovalis, have a broad temporal and spatial distribution. Questionable specimens of $P$. sphaerica were recorded from the Barremian of 
Indonesia (Vogler, 1941), although it was not until the Albian that the species became geographically widespread with further expansion during the Cenomanian -Turonian (Dias-Brito, 2000 and references therein). Pithonella ovalis first appeared in the Albian and very rapidly migrated into Europe, North Africa, the Americas and Asia (DiasBrito, 2000 and references therein). Both species range throughout the Late Cretaceous. These long-ranging species have little biostratigraphical significance, except where there are sudden blooms. The use of these blooms for correlative purposes appears be possible at least between France, Germany and the UK, but the larger events (e.g. that during the late Cenomanian-Turonian) can be recognised on a global scale.

\section{Acknowledgements}

This paper is published with the permission of the Executive Director of the British Geological Survey (N.E.R.C.).

\section{References}

Adams, T. D., Khalili, M., Said, A. K. 1967. Stratigraphic significance of some oligosteginid assemblages from Lurestan Province, northwest Iran. Micropaleontology $13,55-87$.

Aguilera-Franco, N 2003. Cenomanian - Coniacian zonation (foraminifers and calcareous algae) in the Guerrero - Morelos basin, southern Mexico Revista Mexicana de Ciencias Geológicas 20, 202-222 
Bailey, H.W. 1978. A foraminiferal biostratigraphy of the Lower Senonian of southern England. Unpublished C.N.A.A PhD thesis, Plymouth Polytechnic.

Bailey, H.W., Gale, A.S., Mortimore, R.N., Swiecicki, A. and Wood, C.J. 1984. Biostratigraphical criteria for the recognition of the Coniacian to Maastrichtian stage boundaries in the Chalk of north-west Europe, with particular reference to southern England. Bulletin of the Geological Society of Denmark 33, 31-39.

Banner, F. T. 1972. Pithonella ovalis from the Early Cenomanian of England. Micropaleontology 18, 278-284.

Bein, A., Reiss, Z. 1976. Cretaceous Pithonella from Israel. Micropaleontology 22, 8391.

Bertle, R.J., Suttner, T.J. 2005. New biostratigraphic data for the Chikkim Formation (Cretaceous, Tethyan Himalaya, India). Cretaceous Research 26, 882-894.

Bignot, G., Lezaud, L. 1964. Contribution à l'étude des Pithonella de la craie parisienne. Revue de Micropaléontologie 7, 138-152.

Bishop, B.A. 1972. Petrography and origin of Cretaceous limestones, Sierra de Picachos vicinity, Nuevo Leon, Mexico. Journal of Sedimentary Petrology 42, 270286.

Borza, K. 1972. Neue arten der gattung Cadosina Wanner, Pithonella Lorenz und Palinosphaera Reinsh aus der oberen Kreide. Geologica Carpathica 23, 139-150.

Colom, G. 1955. Jurassic-Cretaceous pelagic sediments of the western Mediterranean zone and the Atlantic area. Micropaleontology 1, 109-124. 
Curry, D., Smith, A.J. 1975. New discoveries concerning the geology of the central and eastern parts of the English Channel. Philosophical Transactions of the Royal Society, London A 279, 155-167.

Dias-Brito, D. 2000. Global stratigraphy, palaeobiogeography ands palaeoecology of Albian-Maastrichtian pithonellid calcispheres: impact on Tethys configuration. Cretaceous Research 21, 315-349.

Dufaure, Ph. 1959. Proble'mes stratigraphiques dans le Cre'tace' Supe'rieur des Pays de Bigorre et de Comminges. Revue de Micropaléontologie 2, 99-112.

Dufour, M.T. 1968. Quelques remarques sur les organismes incertae-sedis de la familie des Calcisphaerulidae Bonet (1956). Comptes Rendus de l'Académie des Sciences, Paris, Serie D 266, 1947-1949.

Fensome, R.A., Taylor, F. J. R., Norris, G., Sarjeant, W. A. S., Wharton, D. I., Williams, G.L., 1993. A classification of living and fossil dinoflagellates. Micropaleontology special publication 7: $351 \mathrm{pp}$.

Fütterer, D. 1976. Kalkige Dinoflagellaten ("Calciodinelloidea") und die systematische Stellung der Thoracosphaeroideae. Neues Jahrbuch für Geologie und Paläontologie Abhandlungen 151, 119-141.

Fütterer, D.K.1990. Distribution of calcareous dinoflagellates at the CretaceousTertiary boundary of Queen Maud Rise, Eastern Weddell Sea, Antarctica (ODP Leg 113). Proceedings of the Ocean Drilling Program, Scientific Resullts 113, 533-548

Gale, A.S., Smith, A.B., Monks, N.E.A., Young J.A., Howard, A., Wray, D.S., Huggett, J.M. 2000. Marine biodiversity through the late Cenomanian-Early Turonian: palaeoceanographic controls and sequence stratigraphic biases. Journal of the Geological Society, London 157, 745-757 
Hart, M.B. 1982. Turonian foraminiferal biostratigraphy of southern England. Memoires Museum National d'Histoire Naturelles 46, 203-207.

Hart, M.B. 1991. The late cenomanian global bioevent. Proceedings of the Ussher Society 7, 413-417.

Hart, M.B., Bailey, H.W., Crittenden, S., Fletcher, B.N., Price, R.J., Swiecicki, A. 1989. Cretaceous. In: Jenkins, D.G., Murray, J.W. Stratigraphical index of fossil foraminifera, Second edition, 273-371.

Hart, M. B., Callapez, P. M., Fisher J. K., Hannant, K., Monteiro, J. F., Price, G. D., Watkinson, M. P. 2005 Micropalaeontology and Stratigraphy of the Cenomanian/Turonian boundary in the Lusitanian Basin, Portugal. Journal of Iberian Geology 31, 311-326

Jarvis, I., Carson, G.A., Cooper, M.K.E., Hart, M.B., Leary, P.N., Tocher, B.A., Horne, D., Rosenfeld, A. 1988. Microfossil assemblages and the Cenomanian-Turonian (late Cretaceous) Oceanic Anoxic Event. Cretaceous Research 9, 3-103.

Kaufmann, F.J. 1865. Polythalamien des Seewerkalkes. In: Heer, O (ed.) Die Urwelt der Schweiz, pp. 194-199 (Friedrich Schulthess, Zürich).

Kennedy, W.J. 1969. The correlation of the Lower Chalk of south-eastern England. Proceedings of the Geologists' Association 80, 459-560.

Kennedy, W.J. 1987. Late Cretaceous and Early Palaeocene Chalk Group sedimentation in the Greater Ekofisk area, North Sea Central Graben. Bulletin des Centres de Recherches Exploration-Production Elf Aquitaine 11, 91-126.

Keupp, H. 1980. Pithonella paratabulata n. sp., eine unterkretazische Calcisphaere mit äusserer Paratabulation. Facies 3, 239-249. 
Keupp, H. 1987. Die kalkigen Dinoflagellatenzysten des Mittelalb bis Untercenoman

von Escalles/Boulonnais (N-Frankreich). Facies 16, 37-87 [Springer, Berlin/Heidelberg].

King, C., Bailey, H.W., Burton, C.A., King, D. 1989. Cretaceous of the North Sea. In: Jenkins, D.G., Murray, J.W. Stratigraphical index of fossil foraminifera, Second edition, 372-417.

Marszalek, D.S. 1975. Calcisphere ultrastructure and skeletal aragonite from the alga Acetabularia antillana. Journal of Sedimentary Petrology 45, 266-271

Masters, B. A., Scott, R. W. 1978. Microstructure affinities and systematics of Cretaceous calcispheres. Micropaleontology 24, 210-221.

Mortimore, R.N. 1986. Stratigraphy of the Upper Cretaceous White Chalk of Sussex. Proceedings of the Geologists’ Association 97, 97-139.

Mortimore, R.N., Wood, C.J., Gallois, R.W. 2001. British Upper Cretaceous Stratigraphy. Conservation Review Series, No. 23, 558pp. [Joint Nature Conservation Committee, Peterborough]

Niebuhr, B. 2005 Geochemistry and time-series analyses of orbitally forced Upper Cretaceous marl-limestone rhythmites (Lehrte West Syncline, northern Germany) Geological Magazine 142, 31-55.

Oakman, C,D. Partington, MA. 1998. Cretaceous. 294-349. In: Glennie, KW (ed.)

Petroleum geology of the North Sea: basic concepts and recent advances, $4^{\text {th }}$ edition. 656pp [Wiley-Blackwell]

Olszewska-Nejbert, D. 2004. Development of the Turonian-Coniacian hardground boundary in the Cracow Swell area (Wielkanoc quarry, Southern Poland, Geological Quarterly 48, 159-170. 
Peake, N.B., Hancock, J.M. 1961. The Upper Cretaceous of Norfolk. In: Larwood, G.P., Funnell, B.M. (eds) The Geology of Norfolk. Transactions of the Norfolk and Norwich Naturalists' Society 19, 293-339.

Peake, N.B., Hancock, J.M. 1970. The Upper Cretaceous of Norfolk. In: Larwood, G.P., Funnell, B.M. (eds) The Geology of Norfolk. Transactions of the Norfolk and Norwich Naturalists' Society 19, 293-339 (reprinted with supplement).

Robaszynski, F., Pomerol, B., Masure, E., Bellier, J-P., Decononck, J-F. 2005. Stratigraphy and stage boundaries in reference dections of the Upper Cretaceous Chalk in the east of the Paris Basin: the "Craie 700" Provins boreholes. Cretaceous Research 26, 157-169.

Robaszynski, F., Caron, M., Ame’dro, F., Dupuis, C., Hardenbol, J., Gonza'lez Donoso, J. M., Linares, D., Gartner, S. 1993. Le Cenomanien de la re'gion de Kalaat Senan (Tunisie Central): litho-biostratigraphie et interpre'tation se'quentielles. Revue de Paléobiologie 12, 351-505.

Streng, M., Hildebrand-Habel, T. and Willems, H., 2004.Aproposed classification of archeopyle types in calcareous dinoflagellate cysts. Journal of Paleontology 78: 456483.

Swiecicki, A. 1980. A foraminiferal biostratigraphy of the Campanian and Maastrichtian chalks of the United Kingdom. Unpublished C.N.A.A PhD thesis, Plymouth Polytechnic.

Tappan, H. 1980. The palaeobiology of plant protistids. 1028pp [Freeman, San Fransisco] 
Tew, B.H. 2000. Depositional setting of the Arcola Limestone Member (Campanian) of the Mooreville Chalk, eastern Gulf Coastal Plain. Gulf Coast Association of Geological Societies, Transactions 50, 157-166.

Thomas, H.D. 1932. Origin of spheres in the Georgetown Limestone. Journal of Paleontology 6, 100-101.

Villain, J.-M. 1977. Les Calcisphaerulidae: architectures, calcification de la paroi et phylogenese. Palaeontographica A 159, 139-177.

Villain, J.-M. 1981. Les Calcisphaerulidae: Interet stratigraphiques et Paleoécologique. Crettaceous Research 2, 435-438.

Vogler, J. 1941. Ober-Jura und Kreide von Misol (Niederländisch-Ostinden). Palaeontographica 4, 245-293.

Wendler, J., Willems, H. 2002. Distribution patt5ern of calcareous dinoflagellate cysts across the Cretaceous-Tertiary boundary (Fish Clay, Stevns Klint, Denmark): implications for our understanding of species-selective extinction. In: Kloeberl, C. MacLeod, K.G. (eds) Catastrophic events and Mass extinctions: Impacts and Beyond. Geological Society of America Special Paper 356, 265-275

Wendler, J., Gräfe, K-U., Willems, H 2002. Palaeoecology of calcareous dinoflagellate cysts in the mid-Cenomanian Boreal Realm: implications for the reconstruction of palaeoceanography of the NW European shelf sea. Cretaceous Research 23, 213-229.

Wilkinson, I.P. 2011. Foraminiferal Biozones and their relationship to the lithostratigraphy of the Chalk Group of southern England. Proceedings of the Geologists Association

Willems, H. Tetratropis, eine neue Kalkdinoflagellaten-Gattung (Pithonellideae) aus der Ober-Kreide von Lägerdorf (N-Deutschland). Senckenbergiana Lethaea 70, 239257. 
Willems, H. 1992. Kalk-Dinoflagellaten aus dem Unter-Maastricht der Insel Rügen.

Zeitschrift fur Geologische Wissenschaften 20, 155-178. 


\section{Figure captions}

Fig. 1. Map of the Isle of Wight to show the distribution of the Chalk Group and localities mentioned in the text.

Fig. 2. The distribution of pithonellid blooms (hashed lines) on a regional and global scale in relation to global (dashed line) and North-west European (solid line) sea level changes and major (long arrow) and intermediate (short arrow) maximum flooding surfaces in North West Europe (after Oakman and Partington, 1998).

Fig. 3. The distribution of pithonellids in the Chalk of southern England. Left side of mid line = blooms recorded in southern England (see the text and reference for details); right side of the mid line $=$ blooms recognised in the Isle of Wight (see text for details). 
Click here to download high resolution image

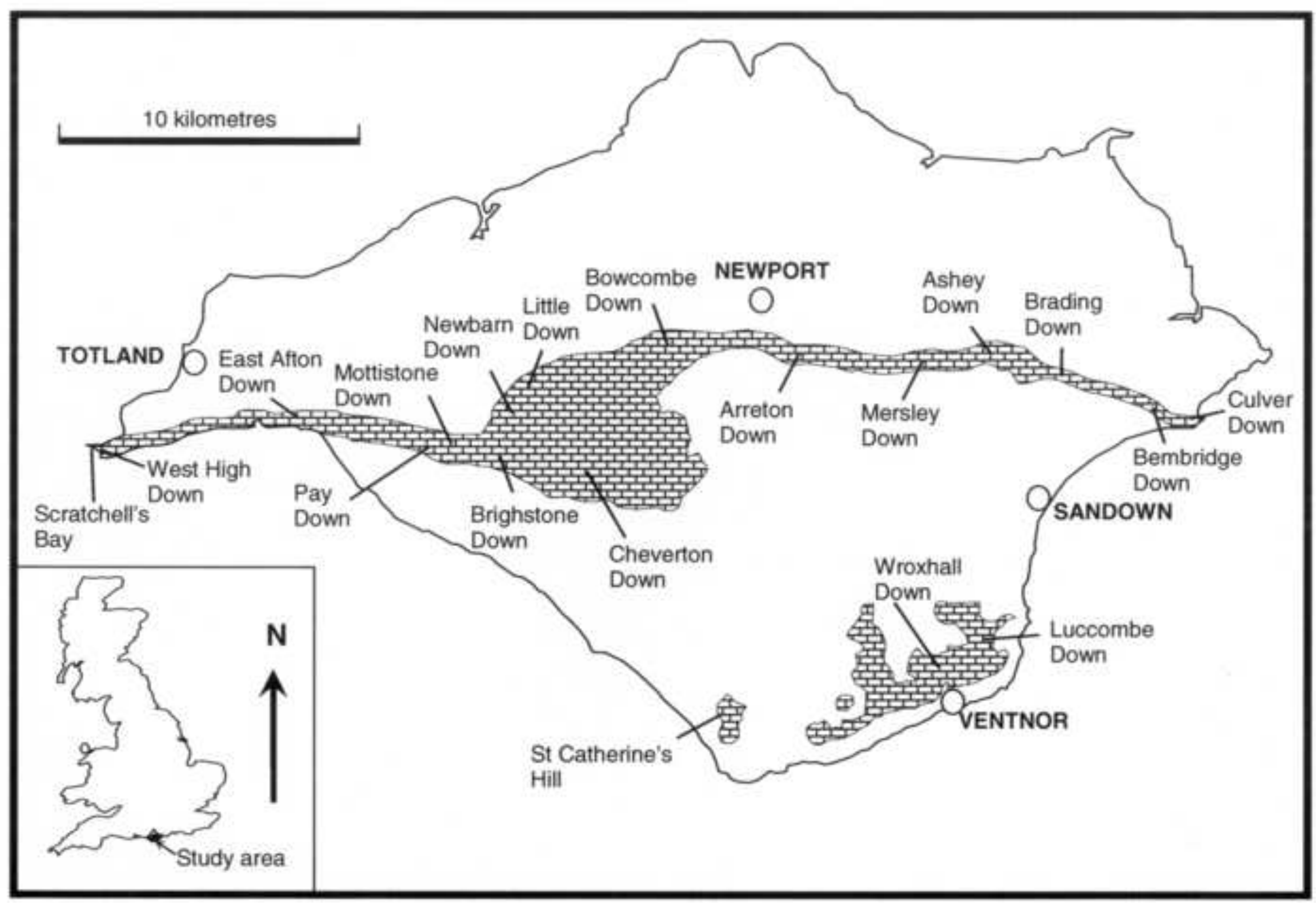

Scratchell's

Bay
St Catherine's

\section{Arreton}

Down

Brighston

Cheverton

Down

Ashey

Down

Brading Down

\section{SANDOWN}

Luccombe

Down 
Figure

Click here to download high resolution image

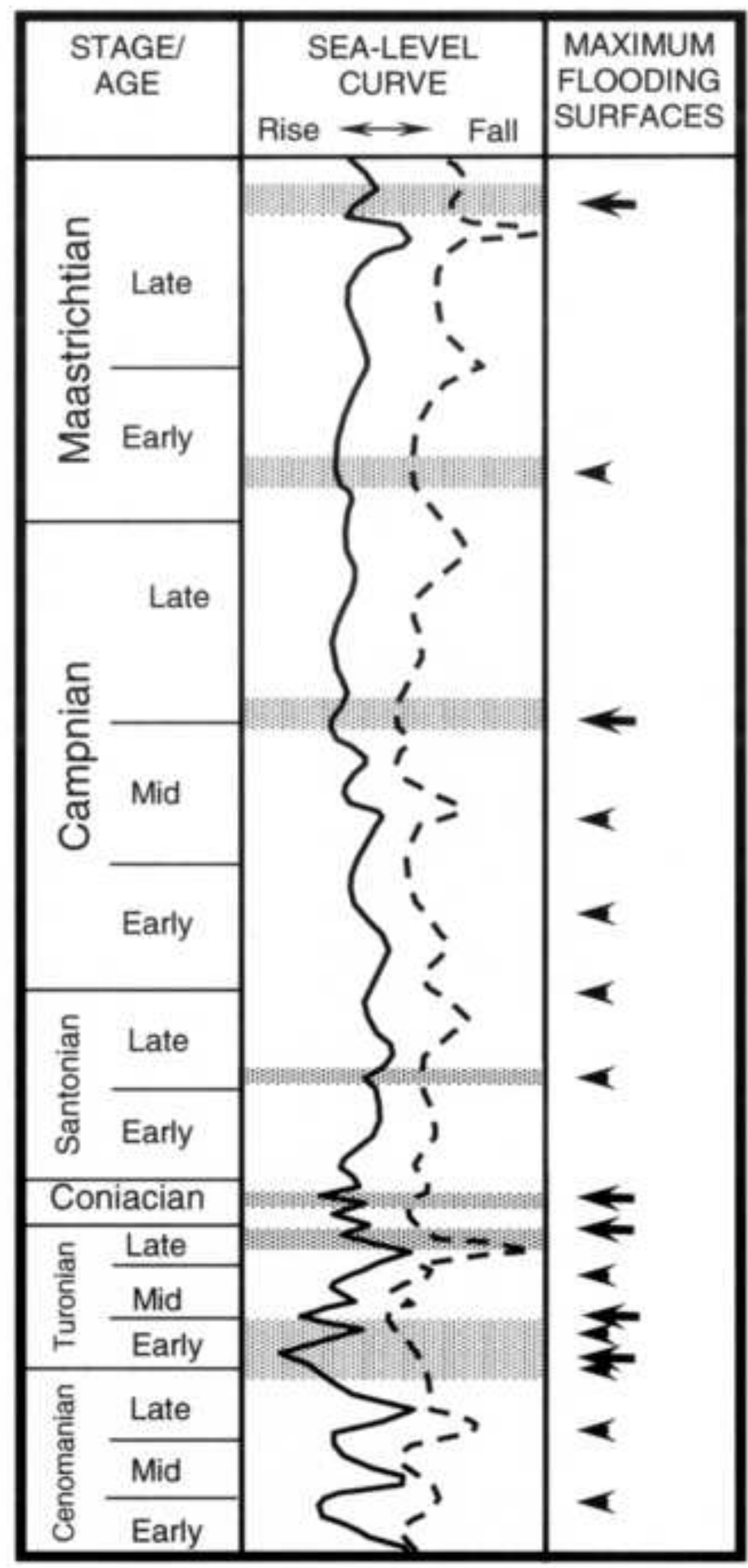


Click here to download high resolution image

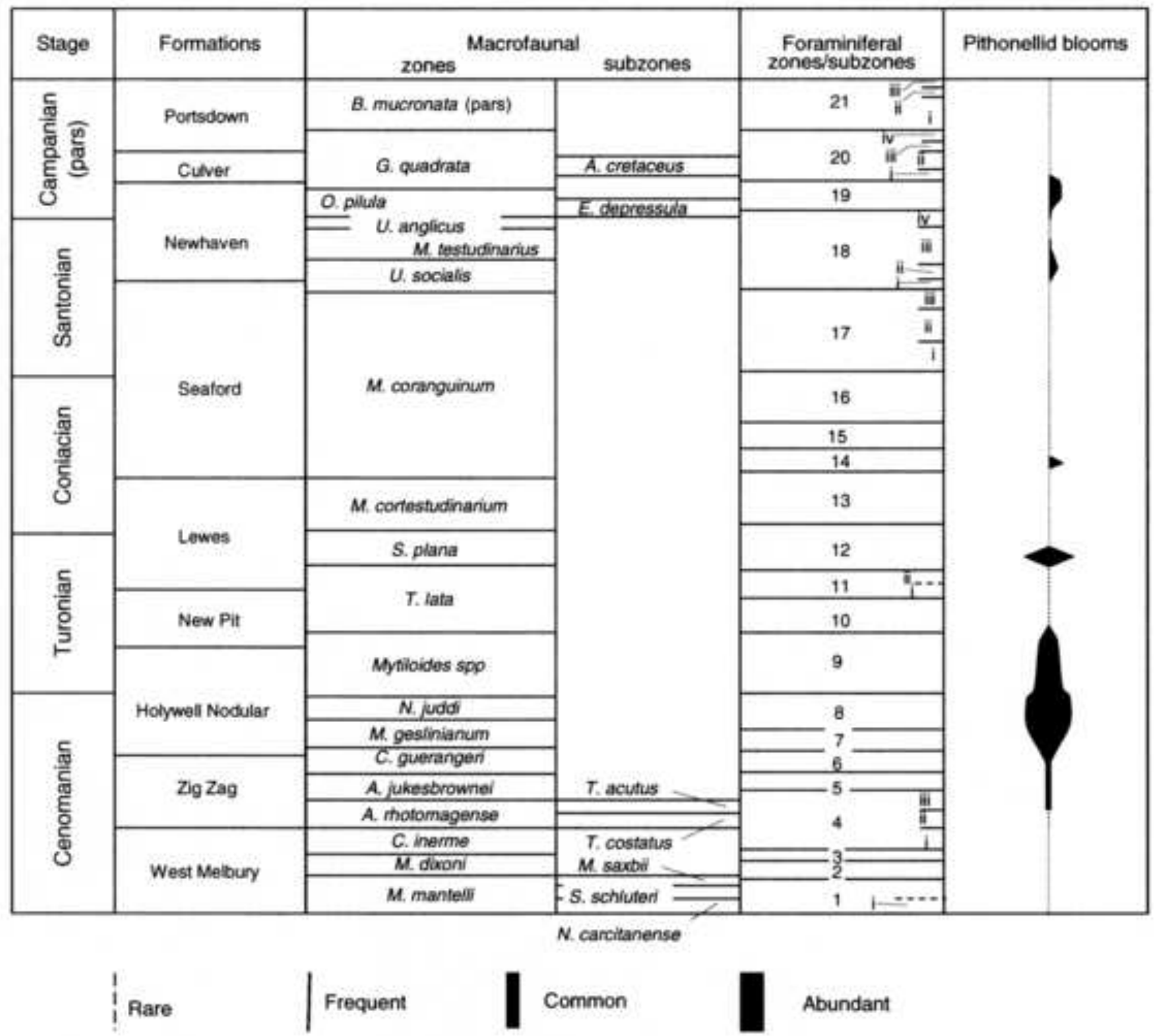

